\title{
Effect of polypropylene thick/basalt composite fibers on the mechanical properties of large dose slag fly ash concrete
}

\author{
Xiangrui Feng, Zhenshu Li*, Anjing Ma \\ Departments of Structural Engineering, Yanbian University, Yanji, Jilin,133002, China
}

\begin{abstract}
In this experiment, the effects of polypropylene thick fiber (PPTF) with different volume admixtures $(0,0.05 \%, 0.10 \%, 0.15 \%, 0.20 \%, 0.25 \%)$ on the compressive strength, splitting tensile strength and bending strength of large admixture of slag fly ash concrete were investigated with short-cut basalt fiber (BF) as a reference. The results show that the polypropylene thick fiber can work well with basalt fiber and improve its strengthening effect of single admixture. And $0.10 \%$ of polypropylene thick fiber and $0.10 \%$ of basalt fibers by volume have the best strengthening effect on the mechanical properties of the large amount of slag fly ash concret.
\end{abstract}

\section{Introduction}

To improve the performance of ordinary concrete with low tensile strength and poor impact resistance, the engineering community has conducted a large number of experiments. Many studies have shown that fiberreinforced concrete can substantially improve the toughness of concrete on the basis of improving its mechanical properties ${ }^{[1]}$. Among them, Lian $\mathrm{Jie}^{[2]}$ et al. studied the effect of short-cut basalt fibers with different aspect ratios and volume dosing on the mechanical properties of concrete, and the results showed that the addition of short-cut basalt fibers can effectively improve the strength of concrete, with a maximum increase of 47 . $5 \%$. Cai Jiangning ${ }^{[3]}$ et al. studied the effect of carbon fiber and steel fiber blending on the mechanical properties of concrete, and the results showed that the best enhancement of compressive strength and tensile strength with the same volume of blended fiber, and the toughness of each group of concrete was significantly improved. Wang Jinlong ${ }^{[4]}$ et al. studied the effect of imitation steel fiber admixture and other factors on the mechanical properties of concrete, and the results showed that when the PPTF admixture is $3 \sim 4 \mathrm{~kg} / \mathrm{m}^{3}$, the admixture of PPTF increases the bridging action and bonding surface between the aggregates, which limits the deformation of concrete and synergizes the force with the aggregates.

Basalt (BF) fiber is made of natural basalt drawn into filaments after high temperature dissolution, which has the advantages of high elastic modulus and tensile strength, corrosion resistance and chemical stability, etc. Moreover, it does not produce toxic substances throughout the production process and can be degraded after disposal ${ }^{[5]}$, which has been widely used in green ecological concrete construction. Polypropylene thick fiber (PPTF) is an alternative product to steel fiber, with synthetic resin as the main raw material, processed through a special process and surface treatment. It has the advantages of corrosion resistance, easy dispersion, easy construction, high fracture strength and strong grip strength $^{[6]}$, and gradually becomes a hot spot for research in the engineering field.

In this paper, the effects of different blending amounts of polypropylene thick fiber on the compressive strength, bending strength and splitting tensile strength of large blended slag fly ash concrete were studied with reference to the blending amounts of short-cut basalt fibers, in order to provide a test basis for the practical application of compound polypropylene thick/basalt fibers.

\section{Test}

\subsection{Test material}

Cement: Yanbian Miaoling Cement Co., Ltd. production, strength grade 42.5 ordinary silicate cement, density of $3150 \mathrm{~kg} / \mathrm{m}^{3}$; fly ash: produced by Tienan Heating Company, Yanji, Jilin Province, with a density of 2200 $\mathrm{kg} / \mathrm{m}^{3}$; slag: S95 grade mineral powder produced by Rongxingda Mineral Powder Plant in Licheng District, Jinan, with a density of $2890 \mathrm{~kg} / \mathrm{m}^{3}$; river sand: fineness modulus of 2.9 , density of $2600 \mathrm{~kg} / \mathrm{m}^{3}$; crushed stone: particle size $5 \sim 25 \mathrm{~mm}$, good grading, density $2700 \mathrm{~kg} / \mathrm{m}^{3}$; water reducing agent: produced by Shandong Greyba Building Materials Co., Ltd, liquid polycarboxylic acid high-efficiency water reducing agent, water reduction rate of $18 \% \sim 25 \%$, dosing of $1.0 \%$; short-cut basalt fiber: produced by Shanghai Chenqi Chemical Technology Co.,as in Figure 1. Polypropylene thick fiber: produced by Taian Lide Engineering Materials Co., as in Figure 2. The

*Corresponding author's E-mail: lizs@ybu.edu.cn 
main technical parameters of the two fibers are shown in Table 1.

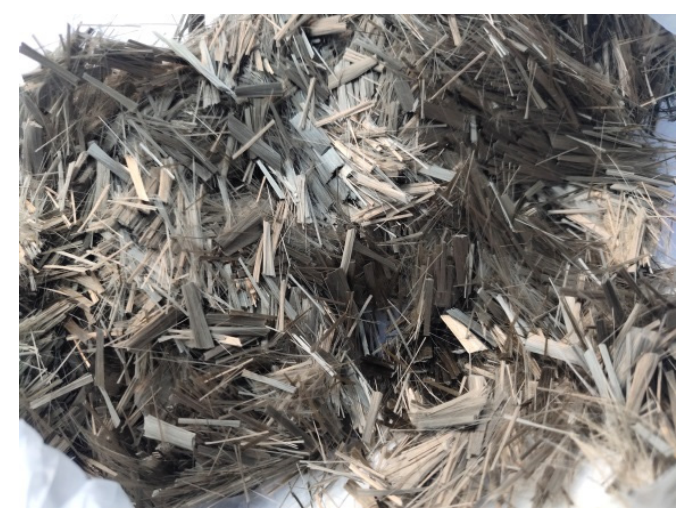

Fig.1 Short-cut basalt fiber

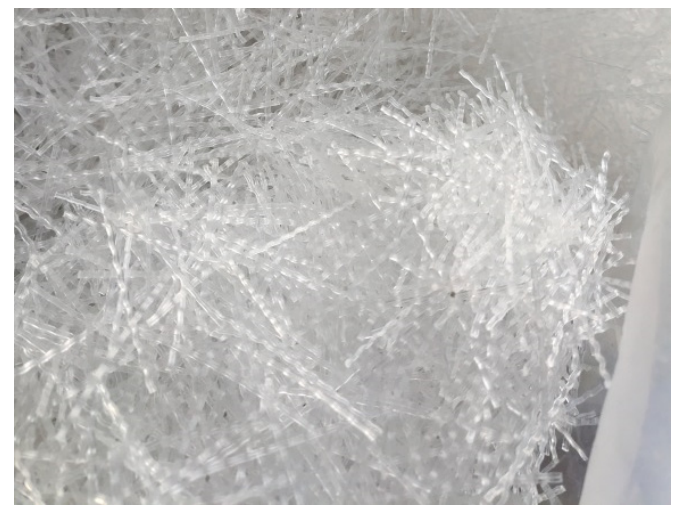

Fig. 2 Polypropylene thick fiber

Table 1. Main technical parameters of BF fiber and PPTF fiber

\begin{tabular}{cccccc}
\hline $\begin{array}{c}\text { Fib } \\
\text { er } \\
\text { typ } \\
\mathrm{e}\end{array}$ & $\begin{array}{c}\text { Length/ } \\
\mathrm{mm}\end{array}$ & $\begin{array}{c}\text { Density } \\
/ \mathrm{kg}-\mathrm{m}- \\
3\end{array}$ & $\begin{array}{c}\text { Tensile } \\
\text { strength/ } \\
\mathrm{MPa}\end{array}$ & $\begin{array}{c}\text { Modulus } \\
\text { of } \\
\text { elasticity } \\
/ \mathrm{CPa}\end{array}$ & $\begin{array}{c}\text { Elonga } \\
\text { tion at } \\
\text { break/ } \\
\%\end{array}$ \\
\hline $\mathrm{BF}$ & 12 & 2.699 & $\geq 2000$ & $\geq 85$ & $\geq 2.5$ \\
\hline $\mathrm{PP}$ & 19 & 0.91 & $400 \sim 550$ & $5 \sim 7.6$ & $\geq 15$ \\
$\mathrm{TF}$ & 19 & & & & \\
\hline
\end{tabular}

\subsection{Experimental design}

Three kinds of specimens were designed for this test, namely, compressive specimen, splitting tensile specimen and flexural specimen. The dimensions of the compressive and splitting specimens are $100 \mathrm{~mm} \times 100$ $\mathrm{mm} \times 100 \mathrm{~mm}$, and the dimensions of the flexural specimens are $100 \mathrm{~mm} \times 100 \mathrm{~mm} \times 400 \mathrm{~mm}$, as shown in Figure 3 . The proportion of the large dose of slag fly ash concrete is shown in Table 2, and the dose of polypropylene thick fiber are $0,0.05 \%, 0.10 \%, 015 \%$, $0.20 \%, 0.25 \%$, and then respectively Six groups of specimens (numbered S0 S5) with the addition of basalt fibers of $0.10 \%$ by volume, as shown in Table 3, to compare the enhancement effect of mixed fiber admixture on the mechanical properties of the mass blended slag fly ash concrete.

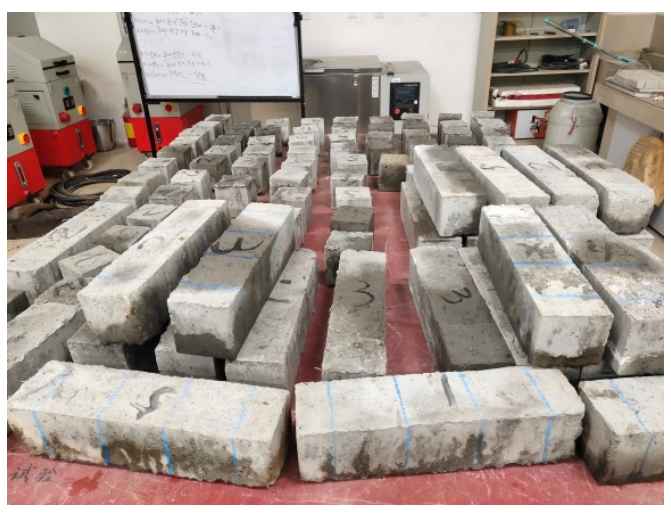

Fig. 3 Fabricated fiber-reinforced high-density slag fly ash concrete

Table 2. Concrete ratio Unit: $\mathrm{kg} / \mathrm{m} 3$

\begin{tabular}{ccccccc}
\hline $\begin{array}{c}\text { Cemen } \\
\mathrm{t}\end{array}$ & $\begin{array}{c}\text { Fly } \\
\text { ash }\end{array}$ & $\begin{array}{c}\text { Sla } \\
\mathrm{g}\end{array}$ & $\begin{array}{c}\text { San } \\
\mathrm{d}\end{array}$ & $\begin{array}{c}\text { Rock } \\
\mathrm{s}\end{array}$ & $\begin{array}{c}\text { Wate } \\
\mathrm{r}\end{array}$ & $\begin{array}{c}\text { Water - } \\
\text { Reducin } \\
\text { g agent }\end{array}$ \\
\hline 264 & $\begin{array}{c}56 . \\
5\end{array}$ & 56.5 & 639 & 1042 & 161 & 3.78 \\
\hline
\end{tabular}

Table 3. Volume dosing of each group of fibers Unit: \%

\begin{tabular}{ccccccc}
\hline & S0 & S1 & S2 & S3 & S4 & S5 \\
\hline BF & 0.1 & 0.1 & 0.1 & 0.1 & 0.1 & 0.1 \\
\hline PPTF & 0 & 0.05 & 0.10 & 0.15 & 0.20 & 0.25 \\
\hline
\end{tabular}

\subsection{Test Method}

The second mixing method was improved ${ }^{[7]}$ : the coarse and fine aggregates and fibers were mixed dry for 30 s until uniform, then cement, fly ash and slag were mixed for $60 \mathrm{~s}$, and finally the water reducing agent was mixed with water and put into the mixer for 180s. After uniform mixing, the concrete was cast and cured at room temperature after 30 s of vibration, and after $24 \mathrm{~h}$, the mold was removed and put into the standard curing room. The test results showed that the fibers did not sink and agglomerate. $7 \mathrm{~d}$ and $28 \mathrm{~d}$ later, the tests of compressive, splitting tensile and flexural properties were carried out according to the test method of mechanical properties of ordinary concrete (GB/T 50081-2002). All tests were carried out on YAD-2000 microcomputer-controlled automatic pressure testing machine produced by Changchun Kexin Testing Instruments Co.

\section{Analysis of experimental results}

\subsection{Compressive strength test}

A total of six groups of specimens were tested for compressive strength, and the damage pattern is shown in Figure 4, and the test results are shown in Table 4. From the table, it can be seen that: except for S5, the compressive strength of the test group with polypropylene thick fiber increased in different magnitudes compared with the compressive strength of the reference group, showing an overall trend of increasing first and then decreasing. The $7 \mathrm{~d}$ and $28 \mathrm{~d}$ compressive strengths 
increased by $12.9 \%(\mathrm{~S} 1)$ and $10.7 \%(\mathrm{~S} 2)$, respectively. The $7 \mathrm{~d}$ strength of concrete specimens increased slowly in the early stage compared with the $28 \mathrm{~d}$ compressive strength, mainly because in the early stage of cement hydration, a large number of admixtures were added to reduce the initial hydration products of cement, which in turn led to the slow secondary hydration of slag fly ash, the activity was not activated and the strength was lower. Later, with the increase of curing time, the slag fly ash gradually reacts completely, and the fly ash and slag produce "superposition effect", which makes the system dense and improves the compressive strength of concrete.

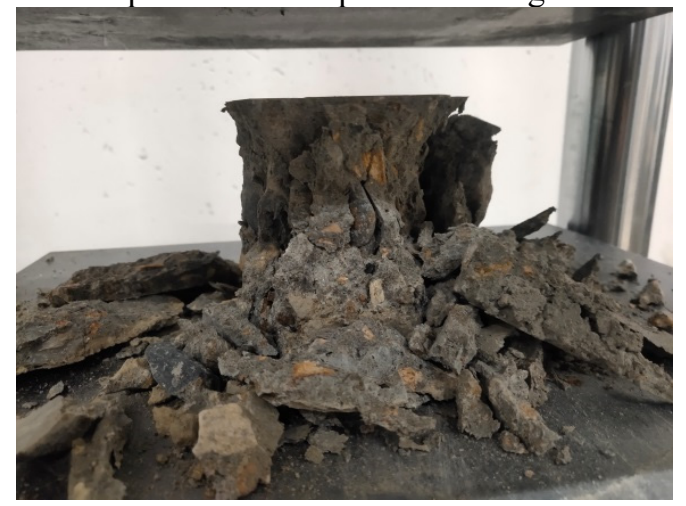

Fig.4. Compression test of specimen

Table 4. Compressive strength test results

\begin{tabular}{|c|c|c|c|c|}
\hline \multirow{2}{*}{$\begin{array}{c}\text { Numb } \\
\text { er }\end{array}$} & \multicolumn{2}{|c|}{$7 d$} & \multicolumn{2}{|c|}{$28 \mathrm{~d}$} \\
\hline & $\begin{array}{c}\text { Strength/ } \\
\mathrm{MPa}\end{array}$ & $\begin{array}{l}\text { Improvem } \\
\text { ent rate } / \%\end{array}$ & $\begin{array}{c}\text { Strength/ } \\
\mathrm{MPa}\end{array}$ & $\begin{array}{l}\text { Improvem } \\
\text { ent rate } / \%\end{array}$ \\
\hline S0 & 27.62 & - & 45.26 & - \\
\hline S1 & 31.18 & 12.9 & 48.72 & 7.6 \\
\hline S2 & 30.17 & 9.2 & 50.11 & 10.7 \\
\hline S3 & 29.81 & 7.3 & 48.96 & 8.2 \\
\hline S4 & 30.05 & 8.3 & 47.01 & 3.9 \\
\hline S5 & 27.26 & -0.01 & 46.78 & 3.4 \\
\hline
\end{tabular}

\subsection{Splitting tensile strength test}

A total of six groups of specimens were tested for splitting tensile strength, and the damage pattern is shown in Fig. 5 , and the test results are shown in Table 5. The increase in tensile strength may be attributed to the fact that both polypropylene thick fiber and basalt fibers have large modulus of elasticity. Exerted a better synergistic effect, and the two fibers formed a uniform three-dimensional disordered distribution system in the concrete, which reduced the internal defects, increased the friction and adhesion between the aggregates, and showed the pull-off of the fibers at the later stage of damage, thus significantly increasing the splitting tensile strength of the test blocks.

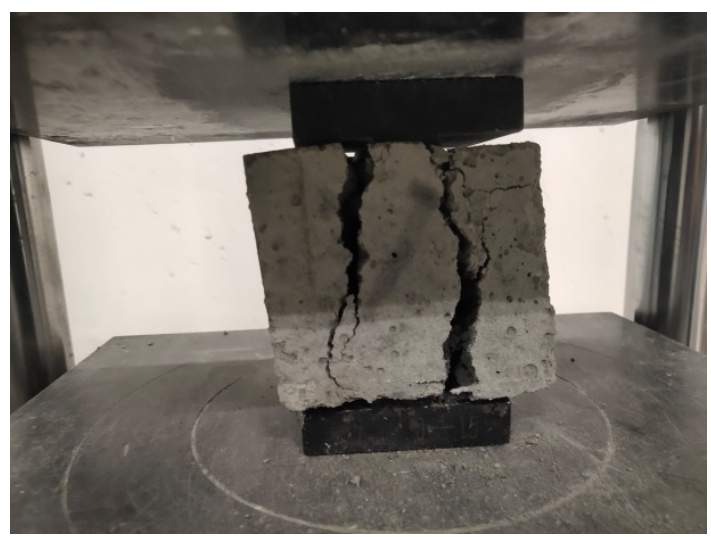

Fig.5. Specimen splitting tensile test

Table 5. Splitting tensile strength test results

\begin{tabular}{ccccc}
\hline \multirow{2}{*}{$\begin{array}{c}\text { Numb } \\
\text { er }\end{array}$} & \multicolumn{2}{c}{$7 \mathrm{~d}$} & \multicolumn{2}{c}{$28 \mathrm{~d}$} \\
\cline { 2 - 5 } & $\begin{array}{c}\text { Strength/ } \\
\text { Mpa }\end{array}$ & $\begin{array}{c}\text { Improvem } \\
\text { ent rate/\% }\end{array}$ & $\begin{array}{c}\text { Strength/ } \\
\text { Mpa }\end{array}$ & $\begin{array}{c}\text { Improvem } \\
\text { ent rate/\% }\end{array}$ \\
\hline S0 & 2.41 & - & 4.58 & - \\
\hline S1 & 3.04 & 26.1 & 5.02 & 9.6 \\
\hline S2 & 3.05 & 27.8 & 5.19 & 13.3 \\
\hline S3 & 3.03 & 25.7 & 5.05 & 10.9 \\
\hline S4 & 2.80 & 16.2 & 4.76 & 3.9 \\
\hline S5 & 2.49 & 3.3 & 4.59 & 0.2 \\
\hline
\end{tabular}

\subsection{Bending strength test}

A total of six groups of specimens were tested for bending strength, and the damage pattern is shown in Figure 6, and the test results are shown in Table 6 . The bending strength of the specimens increased by $22 \%$ (S1) and $14.1 \%(\mathrm{~S} 2)$, reaching 5.05 $\mathrm{MPa}$ and $8.36 \mathrm{MPa}$, respectively, compared with the maximum of the reference group. This is because the larger volume of fiber admixture affects the bonding properties within the concrete itself, which is not conducive to the increase of bending strength.

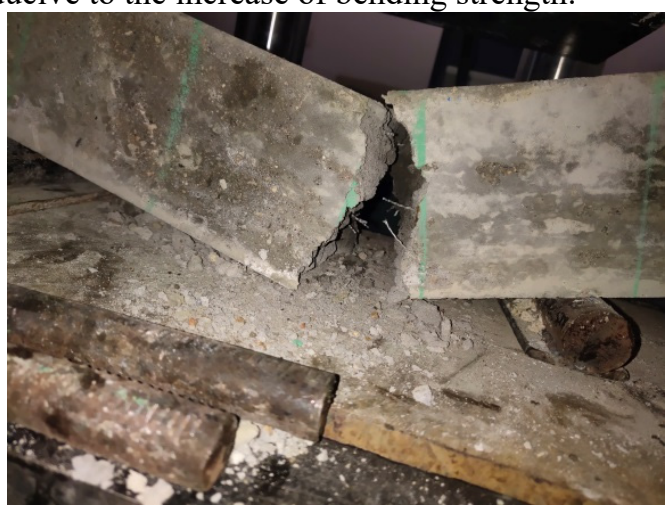

Fig.6. Test piece flexural test

Table 6. Bending strength test results

\begin{tabular}{ccccc}
\hline \multirow{2}{*}{$\begin{array}{c}\text { Numb } \\
\text { er }\end{array}$} & $\begin{array}{c}\text { Strength/ } \\
\mathrm{MPa}\end{array}$ & $\begin{array}{c}\text { Improvem } \\
\text { ent rate/\% }\end{array}$ & $\begin{array}{c}\text { Strength/ } \\
\mathrm{MPa}\end{array}$ & $\begin{array}{c}\text { Improvem } \\
\text { ent rate/\% }\end{array}$ \\
\hline S0 & 4.14 & - & 7.33 & - \\
\hline S1 & 5.05 & 22.0 & 8.08 & 10.2 \\
\hline S2 & 4.82 & 16.4 & 8.36 & 14.1 \\
\hline S3 & 4.91 & 18.6 & 8.23 & 12.3 \\
\hline S4 & 4.62 & 11.6 & 7.76 & 5.9 \\
\hline
\end{tabular}




\begin{tabular}{lllll}
\hline S5 & 4.15 & 0.2 & 7.53 & 2.7 \\
\hline
\end{tabular}

\subsection{Ratio of tension and compression}

The tensile strength of each group of specimens as shown in Table 7, it can be seen that the amount of polypropylene thick fiber on the concrete in the early stage of the tensile ratio enhancement effect is significantly higher than the later, the maximum rate of increase of up to $16.4 \%$. This is because the compressive strength and tensile strength of the concrete in the early stage of growth is more synchronous, polypropylene thick fiber because of the strong tensile properties, the development of cracks has a good hindering effect. And in the late stage of concrete maintenance, the compressive strength continues to grow, but the tensile strength can only grow at a slower rate, resulting in a continuous decrease in the tensile to compressive ratio.

Table 7. Specimen tensile ratio

\begin{tabular}{ccccc}
\hline \multirow{2}{*}{$\begin{array}{c}\text { Numbe } \\
\text { r }\end{array}$} & $\begin{array}{c}\text { Pull-to- } \\
\text { pressur } \\
\text { e ratio }\end{array}$ & $\begin{array}{c}\text { Improveme } \\
\text { nt rate/\% }\end{array}$ & $\begin{array}{c}\text { Pull-to- } \\
\text { pressur } \\
\text { e ratio }\end{array}$ & $\begin{array}{c}\text { Improveme } \\
\text { nt rate/\% }\end{array}$ \\
\hline S0 & 0.0873 & - & 0.1012 & - \\
\hline S1 & 0.0972 & 11.3 & 0.1030 & 1.8 \\
\hline S2 & 0.1011 & 15.8 & 0.1036 & 2.4 \\
\hline S3 & 0.1016 & 16.4 & 0.1031 & 1.9 \\
\hline S4 & 0.0932 & 6.8 & 0.1013 & 0.1 \\
\hline S5 & 0.0913 & 4.6 & 0.0981 & -3.1 \\
\hline
\end{tabular}

\section{Conclusions}

(1)The strength of the large amount of slag fly ash concrete was low at the pre-hydration stage, but at $28 \mathrm{~d}$ the strengths all reached the design index and showed good coordination with polypropylene thick/basalt fibers, which has good prospects for practical engineering applications.

(2) Basalt fiber and polypropylene imitation steel fiber have better superposition effect, which can effectively improve the tensile to compressive ratio of concrete, enhance the ductility of concrete and retard the development of cracks without reducing the strength of concrete.

(3)The optimal dosage in this test is: when the dosage of basalt fiber is $0.10 \%$ and the dosage of polypropylene thick fiber is $0.10 \%$ (S2), the improvement rate of compressive strength is $9.2 \%$ and $10.7 \%$, splitting tensile strength is $27.8 \%$ and $13.3 \%$, and bending strength is $16.4 \%$ and $14.1 \%$ at $7 \mathrm{~d}$ and $28 \mathrm{~d}$, respectively.

\section{Acknowledgments}

Fund project: First-class undergraduate major construction project of Yanbian University (Yanbian University Education Development [2020] No. 16)

\section{References}

1. Li Jian, Effect of short-cut basalt fibers on mechanical properties and microstructure of slag fly ash concrete. Journal of Silicates, 36:727-737(2017)

2. Lian Jie, Experimental study on the mechanical properties of short-cut basalt fiber reinforced concrete. Industrial Construction, 37:8-10(2007)

3. Cai Jiangning, Research on hybrid fiber toughened high performance concrete. Journal of Three Gorges University (Natural Science Edition), 2002.01:4244(2002)

4. Wang JL, Study on the main influencing factors of strength and permeability performance of new pervious concrete. New Building Materials, 11:7174(2017)

5. Hu Linna, Study on basalt fiber composite type material and its degradation mechanism. [D] Hebei University of Technology(2003)

6. Gao Rundong, Experimental study of polypropylene thick fiber (PPTF) permeable concrete. New Building Materials, 42: 1-3+42(2015)

7. Peng Miao, Experimental study on the basic mechanical properties of basalt fiber concrete. Concrete, 2012.01::74-75(2012) 